\title{
Lysophosphatidylcholine suppresses apoptosis and induces neurite outgrowth in PC12 cells through activation of phospholipase D2
}

\author{
Doo Hee Yun ${ }^{1 *}$, Eun Su Jeon ${ }^{1 *}$, \\ Sang-Min Sung ${ }^{2}$, Sung Ho Ryu ${ }^{3}$ and \\ Jae Ho Kim ${ }^{1,4}$ \\ ${ }^{1}$ Research Center for Ischemic Tissue Regeneration and \\ Medical Research Institute \\ College of Medicine, Pusan National University \\ Busan 602-739, Korea \\ ${ }^{2}$ Department of Neurology \\ Busan Medical Center \\ Busan 611-072, Korea \\ ${ }^{3}$ Division of Molecular and Life Sciences \\ Pohang University of Science and Technology \\ Pohang 790-784, Korea \\ ${ }^{4}$ Corresponding author: Tel, 82-51-240-7732; \\ Fax, 82-51-246-6001; E-mail, jhkimst@pusan.ac.kr \\ *These authors contributed equally to this work.
}

\section{Accepted 9 June 2006}

Abbreviations: LPA, lysophosphatidic acid; LPC, lysophosphatidylcholine; MTT, 3-(4,5-dimethylthiazol-2-yl)-2,5-diphenyltetrazolium bromide; NGF, nerve growth factor; PA, phosphatidic acid; PBtOH, phosphatidylbutanol; PLA2, phospholipase A2; PLD, phospholipase D

\footnotetext{
Abstract

Lysophosphatidylcholine (LPC) is a bioactive lipid generated by phospholipase A2-mediated hydrolysis of phosphatidylcholine. In the present study, we demonstrate that LPC stimulates phospholipase D2 (PLD2) activity in rat pheochromocytoma PC12 cells. Serum deprivation induced cell death of PC12 cells, as demonstrated by decreased viability, DNA fragmentation, and increased sub-G1 fraction of cell cycle. LPC treatment protected PC12 cells partially from the cell death and induced neurite outgrowth of the cells. Overexpression of PLD2 drastically enhanced the LPC-induced inhibition of apoptosis and neuritogenesis. Pretreatment of the cells with 1-butanol, a PLD inhibitor, completely abrogated the LPC-induced inhibition of apoptosis and neurite outgrowth in PC12 cells overexpressing PLD2. These results indicate that LPC possesses the neurotrophic effects, such as anti-apoptosis and neurite outgrowth, through activation of PLD2.
}

Keywords: apoptosis; lysophosphatidylcholines; neurites; PC12 cells; phospholipase D2

\section{Introduction}

Axons are guided to their targets during development by a combination of contact mediated and diffusible cues that are either attractive or repulsive (Paves and Saarma, 1997), and the growth cone at the nerve fiber terminus is believed to guide the axon by sampling the environment for either positive or negative signals using filopodial and lamellar protrusions (Goodman, 1996; Zheng et al., 1996; Mueller, 1999). Lysophosphatidylcholine (LPC) is a major plasma lipid component that is generated by phospholipase A2 (PLA2)-mediated hydrolysis of phosphatidylcholine under physiological and pathological conditions (Prokazova et al., 1998; Macphee, 2001), and secretory PLA2 has been demonstrated to stimulate neuritogenesis through generation of LPC in PC12 cells (Ikeno et al., 2005). These results suggest that LPC plays a pivotal role in axonal outgrowth and guidance by regulating neuritogeneis. However, the molecular mechanisms underlying the LPC-induced neurite outgrowth have not yet been clearly determined.

Phospholipase D (PLD) catalyzes the hydrolysis of phosphatidylcholine to generate phosphatidic acid (PA), and PA can further be metabolized to diacylglycerol by PA phosphohydrolase. By producing PA and diacylglycerol, PLD has been implicated in a wide range of physiological responses, such as membrane trafficking, cell proliferation and differentiation, cytoskeletal reorganization, respiratory burst, and apoptosis (Frohman et al., 1999; Kim et al., 1999a; Exton, 2002). Up to date, two PLD isozymes, PLD1 and PLD2, have been identified (Colley et al., 1997a, b; Park et al., 1997; Lopez et al., 1998), and these PLD isozymes are shown to be differentially regulated by several factors, including ARF, Rho A, protein kinase $C$, and unsaturated fatty acids (Frohman et al., 1999; Kim et al., 1999a; Exton, 2002). It has been reported that $\mathrm{Ca}^{2+}$-dependent activation of cPLA2 in leukocytes results in activation of PLD2, but not PLD1, through generation of LPC (Kim et al., 1999b), possibly implicating the LPC-dependent PLD2 activation in immune responses. However, physiological roles of the LPC- 
stimulated PLD2 activity in neuronal cells have not yet been clarified.

PC12 cells, derived from a rat adrenal medullary pheochromocytoma tumor, are commonly used for studies of neuronal differentiation and cell death. It is well established that deprivation of either serum or trophic factor/nerve growth factor (NGF) induces apoptosis, and that neurotrophic factors can stimulate neuritogenesis of PC12 cells (Levi et al., 1988). Overexpression of PLD2 prevented hydrogen peroxide-induced apoptosis of PC12 cells (Lee et al., 2000), suggesting an anti-apoptotic function of PLD2 in neuronal cells. However, a question of whether the LPC-stimulated PLD2 activation is involved in the regulation of neurite outgrowth and neuronal apoptosis has not yet been studied. In the present study, we demonstrated for the first time that LPC acts as a neurotrophic factor to stimulate neuritogenesis and survival through PLD2-dependent pathway.

\section{Materials and Methods}

\section{Materials}

Tissue culture supplies were purchased from Corning (Corning, NY). Fetal bovine serum and equine serum were purchased from Hyclone (Logan, UT). $\left[{ }^{3} \mathrm{H}\right]$ Myristic acid $(54 \mathrm{Ci} / \mathrm{mmol})$ was from Amersham International (Buckinghamshire, UK). Silica gel 60 TLC plates were purchased from Merck (Darmstadt, Germany). 1-Palmitoyl-lysophosphatidylcholine (LPC) was purchased from Avanti Polar Lipids, Inc. (Alabaster, AL). Tetracycline, propidium iodide, 3-(4,5dimethylthiazol-2-yl)-2,5-diphenyltetrazolium bromide (MTT), 1-butanol, and 2-butanol were purchased from Sigma (St. Louis, MO).

\section{Cell culture}

Rat pheochromocytoma PC12 Tet-Off cells, i.e. PLD1inducible PC12 cell line (PC12-A12) and PLD2inducible PC12 cell line (PC12-F12), were cultured at $37^{\circ} \mathrm{C}$ in a humidified $5 \% \quad \mathrm{CO}_{2}$ atmosphere in high-glucose Dulbecco's modified Eagle's medium supplemented with $10 \%$ equine serum, $5 \%$ fetal calf serum, and $0.5 \mu \mathrm{g} / \mathrm{ml}$ tetracycline as previously described (Lee et al., 2000). Expression of PLD isozymes was induced by culturing the PC12 Tet-Off cell lines in the growth medium without tetracycline.

\section{Immunoblot analysis}

Cells were lysed with lysis buffer $(20 \mathrm{mM}$ Tris, $\mathrm{pH}$ 7.5, 1 mM EDTA, 1 mM EGTA, 1\% Triton X-100, 1\% cholic acid, $1 \mathrm{mM}$ phenylmethylsulfonyl fluoride, 10 $\mu \mathrm{g} / \mathrm{ml}$ leupeptin). Lysates were resolved by sodium dodecyl sulfate-polyacrylamide gel electrophoresis and subsequently transferred to nitrocellulose membrane (Schleicher and Schuell, BA85). Blocking was performed in TTBS buffer [10 mM Tris- $\mathrm{HCl}(\mathrm{pH} 7.5)$, $150 \mathrm{mM} \mathrm{NaCl}$, and $0.05 \%$ Tween 20] with $5 \%$ (wt/vol) skimmed milk powder. The membranes were then incubated with anti-PLD antibody for $2 \mathrm{~h}$ at room temperature. The immunoblots were subsequently washed, incubated with horseradish peroxidaseconjugated secondary antibodies (Kirkegaard and Perry Laboratories, Inc.) for $1 \mathrm{~h}$ at room temperature, rinsed four times in TTBS buffer, and the bound antibodies were visualized using the enhanced chemiluminescence Western blotting system (ECL, Amersham Biosciences).

\section{Measurement of PLD activity}

PLD activity was determined by measuring the formation of phosphatidylbutanol (PBtOH), the product of PLD-mediated transphosphatidylation, in the presence of 1-butanol. Thus, PC12 cells were seeded onto poly-D-lysine-coated 6-well tissue culture plates at $1 \times 10^{6}$ cells/well, cultured in the growth medium in the absence or presence of $0.5 \mu \mathrm{g} / \mathrm{ml}$ tetracycline for $24 \mathrm{~h}$, serum-starved for $20 \mathrm{~h}$, and then loaded with $\left[{ }^{3} \mathrm{H}\right]$ myristic acid $(3 \mu \mathrm{Ci} / \mathrm{ml})$ for $4 \mathrm{~h}$. The $\left[{ }^{3} \mathrm{H}\right] \mathrm{my}-$ ristic acid-labeled cells were treated with LPC in the presence of $0.5 \% 1$-butanol $(\mathrm{v} / \mathrm{v})$ for the indicated times at $37^{\circ} \mathrm{C}$. After the incubation, the medium was aspirated, and $0.4 \mathrm{ml}$ of ice-cold methanol was added to each well. The cells were then scraped into an Eppendorf tube, and chloroform and $0.1 \mathrm{~N} \mathrm{HCl}$ were added, resulting in a final chloroform/ methanol/0.1 $\mathrm{N} \mathrm{HCl}$ ratio of $1: 1: 1(\mathrm{v} / \mathrm{v} / \mathrm{v})$. After vortexing, the tubes were centrifuged at 15,000 $\times g$ for $1 \mathrm{~min}$, and the organic phase was harvested, dried, and spotted onto a Silica Gel 60 TLC plate, which was then developed with chloroform/methanol/acetic acid mixture (9/1/1, v/v/v). The amounts of labeled PBtOH and total lipids were determined by using Fuji BAS-2000 image analyzer (Tokyo, Japan).

\section{Neurite outgrowth assay}

For determination of neurite outgrowth, the PC12 cells at $4.5 \times 10^{3}$ cells $/ \mathrm{cm}^{2}$ were seeded in the growth medium in poly-D-lysine-coated 24-well culture plates in the absence or presence of $0.5 \mu \mathrm{g} / \mathrm{ml}$ tetracyline, allowed to grow for $24 \mathrm{~h}$, and exposed to serum-free medium supplemented with $10 \mu \mathrm{M}$ LPC in the absence or presence of tetracycline. After 72 $h$, neurite outgrowth was quantified by taking four random photographs/well; Neurite length was described as the distance between the cell periphery and the tip of neurite, and total length of multiple neurites per cell was calculated. 


\section{Cell viability assay}

Cell viability was determined by MTT assay, as previously described (Alley et al., 1988). For MTT assay, the stock solution ( $5 \mathrm{mg} / \mathrm{ml}$ MTT) was added to each well of the 24-well plate seeded with PC12 cells to a final $0.5 \mathrm{mg} / \mathrm{ml}$ concentration. The plate was incubated at $37^{\circ} \mathrm{C}$ for $2 \mathrm{~h}$, and formazan granules generated by live cells were dissolved in $100 \%$ dimethylsulfoxide, and absorbance at $570 \mathrm{~nm}$ was monitored by using a PowerWave microplate spectrophotometer (Bio-Tek Instruments, Inc. Winooski, VT).

\section{Flow cytometric analysis}

Cell cycle was analyzed by fluorescence-activated cell sorting, following staining with propidium iodide.
Cells were collected by centrifugation, washed with PBS, and permeabilized overnight at $4^{\circ} \mathrm{C}$ in $70 \%$ ethanol containing $0.5 \%$ Tween 20 . The permeabilized cells were incubated with $50 \mu \mathrm{g} / \mathrm{ml}$ propidium iodide and $0.1 \mathrm{mg} / \mathrm{ml}$ RNase A (Sigma) for $30 \mathrm{~min}$ at $37^{\circ} \mathrm{C}$ and analyzed for apoptosis. Cells with sub- $\mathrm{G}_{1}$ propidium iodide incorporation were considered as apoptotic, and the percentage of apoptotic cells was calculated as the ratio of events on sub- $G_{1}$ to events from the whole population.

\section{Analysis of DNA fragmentation}

Cells were lysed in a buffer, containing $10 \mathrm{mM}$ Tris- $\mathrm{HCl}(\mathrm{pH} 7.4), 150 \mathrm{mM} \mathrm{NaCl}, 5 \mathrm{mM}$ EDTA, and $0.5 \%$ Triton $\mathrm{X}-100$, for $30 \mathrm{~min}$ on ice. Lysates were vortexed and cleared by centrifugation at $12,000 \times$
A

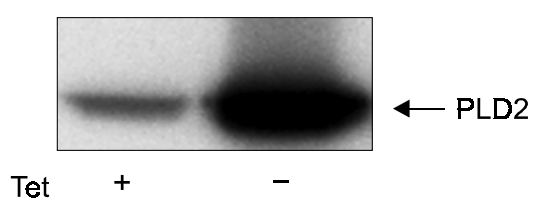

C

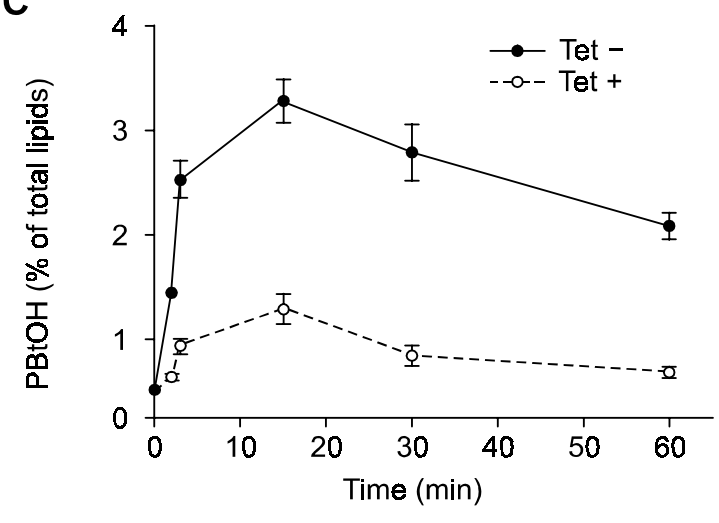

B

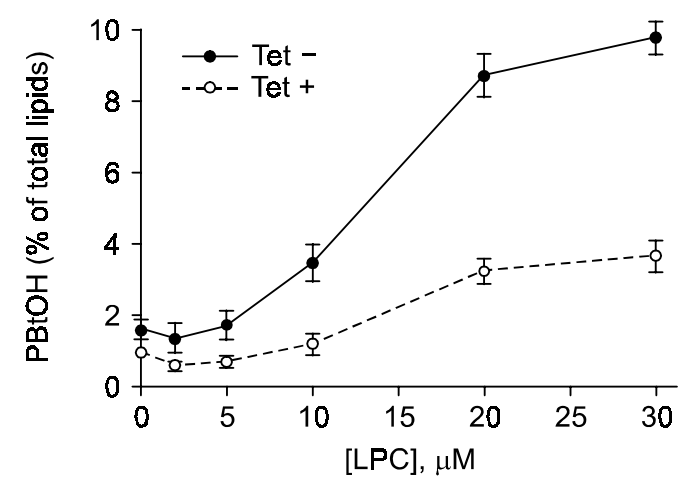

D

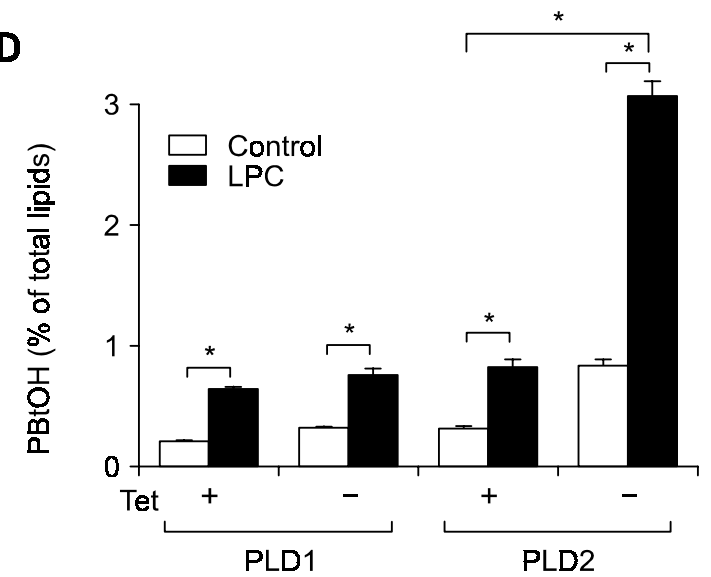

Figure 1. Dose- and time-dependent stimulation of PLD2 activity in PC12 cells by LPC. (A) PC12-F12 cells were cultured in the absence (Tet -) or presence (Tet +) of $0.5 \mu \mathrm{g} / \mathrm{ml}$ tetracycline for $24 \mathrm{~h}$, and expression of PLD2 was confirmed by Western blotting using rabbit anti-PLD antibody. Representative data from three independent experiments are shown. (B) PC12-F12 cells were cultured in the absence (Tet -) or presence $\left(\right.$ Tet + ) of $0.5 \mu \mathrm{g} / \mathrm{ml}$ tetracycline for $48 \mathrm{~h}$, and labeled with $\left.{ }^{3} \mathrm{H}\right]$ myristic acid for $4 \mathrm{~h}$. The $\left[{ }^{3} \mathrm{H}\right] \mathrm{myristic}$ acid-labeled cells were treated with indicated concentrations of LPC for $15 \mathrm{~min}$. (C) The $\left[{ }^{3} \mathrm{H}\right]$ myristic acid-labeled cells were stimulated with $10 \mu \mathrm{M}$ LPC for indicated times. (D) PC12-A12 and PC12-F12 cells were cultured in the absence or presence of tetracycline, labeled with $\left.{ }^{3} \mathrm{H}\right] \mathrm{myristic}$ acid, and then treated with $10 \mu \mathrm{M}$ LPC for $15 \mathrm{~min}$. The amount of $\left[^{3} \mathrm{H}\right] \mathrm{PBtOH}$ formed was determined as described in "Materials and methods". Data represent average values \pm S.E. of triplicate determinants. * indicates $P<0.05$. 
$g$ for $20 \mathrm{~min}$. Fragmented DNA in the supernatant was extracted with an equal volume of neutral phenol:chloroform:isoamyl alcohol mixture (25:24:1) and electrophoretically analyzed on $1.5 \%$ agarose gels containing $0.1 \mu \mathrm{g} / \mathrm{ml}$ ethidium bromide.

\section{Results}

\section{Selective activation of phospholipase D2 in PC12 cells by LPC}

In the present study, we used an established PC12 Tet-Off cell line, PC12-F12 cells, in which PLD2 expression is inducible under the control of an inducible tetracycline-regulated promoter (Lee et al., 2000). As shown in Figure $1 \mathrm{~A}$, in the presence of tetracycline, PLD2, but not PLD1, was endogenously expressed in the PC12-F12 cells, and the removal of tetracycline from the culture media increased the expression level of PLD2. To elucidate whether LPC stimulated the PLD2 activity in the cells, we determined the effect of LPC on the PLD activity in the absence or presence of tetracycline. In the presence of tetracycline, LPC dose-dependently increased the endogenous PLD activity with an $\mathrm{EC}_{50}$ of approximately $15 \mu \mathrm{M}$ (Figure $1 \mathrm{~B}$ ), and the removal of tetracycline further increased the PLD activity. As shown in Figure 1C, LPC time-dependently increased the PLD activity with a maximum at $15 \mathrm{~min}$, and the LPC-induced PLD activity was further augmented by overexpression of PLD2. To delineate whether the LPC-induced stimulation of PLD activity was specific to PLD2, we determined the effect of LPC on
PLD1-inducible PC12 cells (PC12-A12 cells). In contrast to the robust increase of the LPC-induced PLD activity in the PLD2-overexpressing cells, the LPCinduced PLD activity in the PC12-A12 cells was not affected by enhanced expression of PLD1 (Figure 1D). These results suggest that PLD2, but not PLD1, is specifically involved in the LPC-stimulated PLD activity in PC12 cells.

\section{LPC-induced activation of PLD2 increases neurite outgrowth of PC12 cells}

Secretory PLA2 has been shown to stimulate neuritogenesis in PC12 cells through generation of LPC (Ikeno et al., 2005; Masuda et al., 2005). Therefore, to explore the role of LPC-stimulated PLD2 activity in neuritogenesis of PC12 cells, we examined the effect of LPC on the length of neurites of PC12-F12 cells in the absence or presence of tetracycline. As shown in Figure 2A, treatment of PC12-F12 cells with LPC resulted in neurite outgrowth of the cells in the presence of tetracycline. Furthermore, overexpression of PLD2 by the removal of tetracycline from the culture medium drastically increased the length of neurites induced by LPC treatment. (Figure 2A and $2 \mathrm{~B}$ ). These results led us to conclude that LPC-induced PLD2 activation stimulates the neuritogenesis of PC12 cells.

\section{LPC-induced activation of PLD2 prevents serum starvation-induced apoptosis of PC12 cells} To study whether the LPC-stimulated PLD2 acti-
A

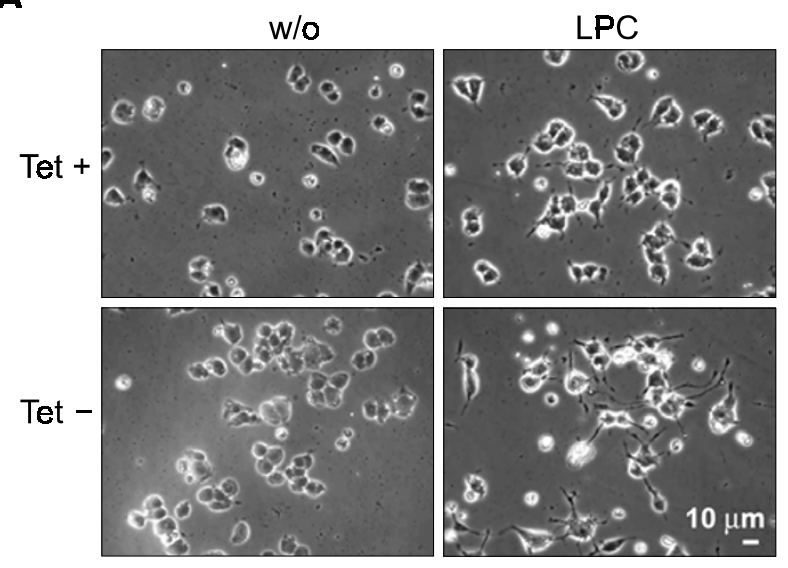

B

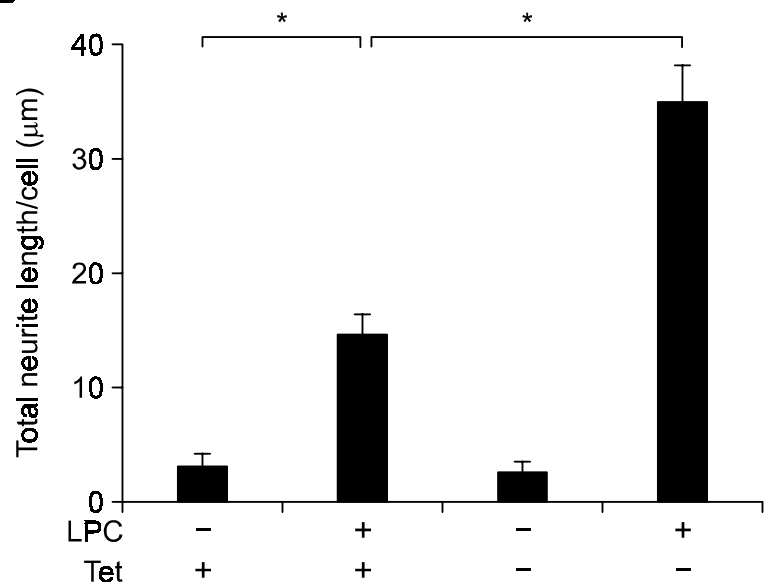

Figure 2. Effects of LPC on neurite outgrowth of PC12 cells. (A) PC12-F12 cells were cultured in growth medium in the absence or presence of 0.5 $\mu \mathrm{g} / \mathrm{ml}$ tetracycline for $24 \mathrm{~h}$. The cells were then exposed to serum-free medium containing vehicles or $10 \mu \mathrm{M} \mathrm{LPC}$ in the absence or presence of tetracycline for $72 \mathrm{~h}$. Phase contrast images were photographed by a digital CCD camera equipped in an inverted microscope (Leica DM IRB) at $\times 200$. Representative data from three independent experiments are shown. (B) Neurite lengths were measured for 100 cells, and the total neurite length per cell was calculated. The data are mean \pm S.E. * indicates statistical significance $(P<0.05)$. 
A

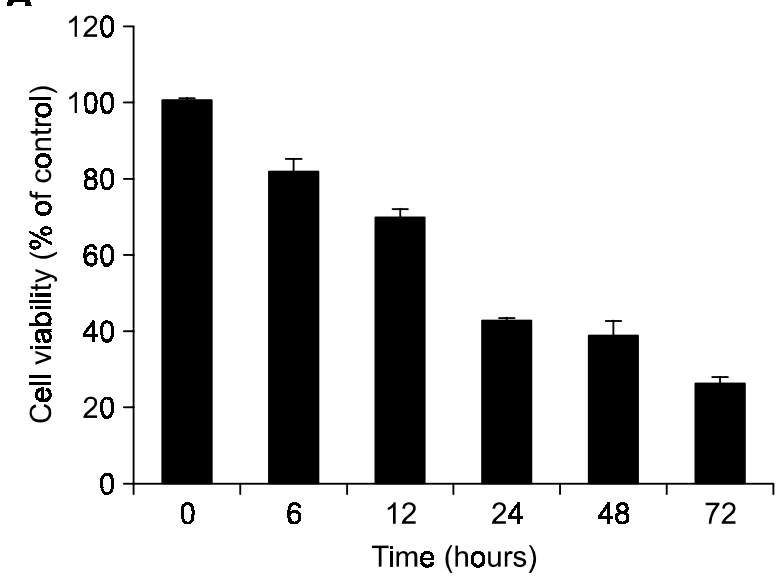

B

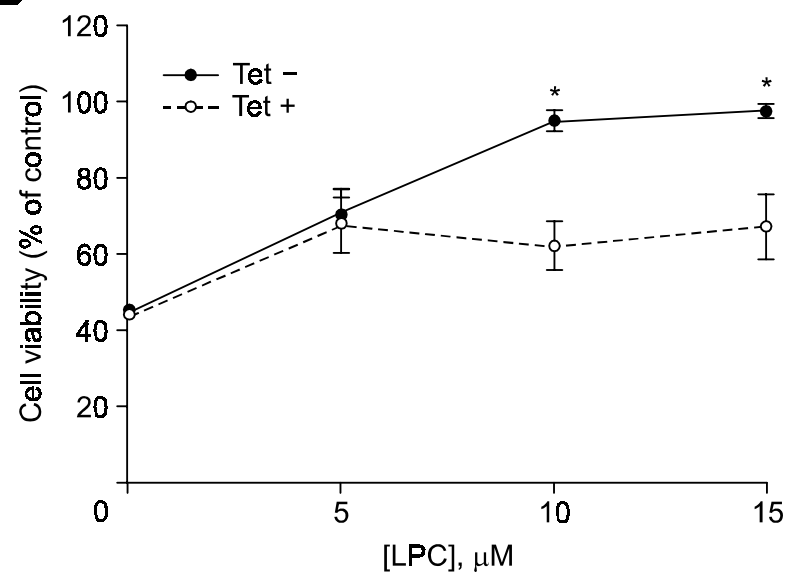

Figure 3. Effects of LPC-induced PLD2 activation on serum-starved PC12 cell death. (A) PC12-F12 cells were maintained in serum-free medium containing $0.5 \mu \mathrm{g} / \mathrm{ml}$ tetracycline for the indicated time. (B) PC12-F12 cells were cultured in growth medium in the absence or presence of $0.5 \mu \mathrm{g} / \mathrm{ml}$ tetracycline for $24 \mathrm{~h}$, and then exposed to serum-free medium supplemented with indicated concentrations of LPC in the absence or presence of tetracycline for $72 \mathrm{~h}$. Cell viability was determined by MTT assay. Data are average values \pm S.E. of triplicate determinations. * indicates statistical significance $(P<0.05)$.

vation could affect the viability of PC12 cells, we determined the effects of LPC on serum starvationinduced cell death. Thus, PC12-F12 cells were maintained in the growth medium containing tetracycline, and then exposed to serum-free medium for the indicated time before measurement of cell viability. As shown in Figure $3 A$, cell viability was time-dependently decreased until $72 \mathrm{~h}$. When PC12F12 cells were exposed to serum-free medium containing the indicated concentration of exogenous LPC, the serum deprivation-induced cell death of PC12-F12 cells in the presence of tetracycline was slightly restored by the addition of LPC (Figure 3B). Interestingly, however, when the expression level of PLD2 was elevated by the removal of tetracycline, the cell viability was drastically increased by LPC treatment with a maximal increase at $10 \mu \mathrm{M}$. These results indicate that LPC-induced stimulation of PLD2 activity ameliorates serum-starved cell death.

To confirm the anti-apoptotic effect of the LPCstimulated PLD2 activation, we next measured the effect of LPC on the cell cycle of PC12 cells by using flow cytometry analysis. PC12-F12 cells were treated with serum free medium containing vehicles or 10 $\mu \mathrm{M}$ LPC for $72 \mathrm{~h}$, and sub-G1 phase DNA content, which indicates apoptotic cells, was then determined by propidium iodide staining and subsequent flow cytometric analysis. In the presence of tetracycline, the percentage of sub-G1 phase cells was increased from $8.7 \pm 1.0 \%$ (control) to $54.7 \pm 6.7 \%$ after serum deprivation for $72 \mathrm{~h}$, and LPC treatment had a marginal effect on the recovery of the serum starvation-induced cell death (Figure 4A and 4B). In contrast, however, LPC treatment in the absence of tetracycline significantly decreased the percentage of sub-G1 phase DNA contents from $52.8 \pm 2.8 \%$ (w/o) to $22.6 \pm 0.9 \%$ (LPC). Consistent with these results, serum starvation of PC12-F12 cells for $72 \mathrm{~h}$ elicited DNA fragmentation in the absence or presence of tetracycline, and LPC treatment of the cells with enhanced expression of PLD2 by the removal of tetracycline diminished the serum starvation-induced DNA fragmentation (Figure 4C). However, treatment of the cells with LPC in the presence of tetracycline had a marginal effect on the DNA fragmentation. These results indicate that LPC-stimulated activation of PLD2 suppresses the cell death of PC12 cells.

\section{Inhibition of PLD2 activity prevents the LPC-induced survival and neurite outgrowth of PC12 cells}

To confirm whether PLD2 is responsible for the increased survival and neurite outgrowth of PC12 cells in response to LPC, we determined the effect of 1-butanol, a PLD inhibitor, on cell viability and neurite outgrowth in the absence or presence of LPC. As shown in Figure $5 \mathrm{~A}$, the cell viability in the absence of tetracycline was drastically increased by LPC treatment, and the LPC-induced increase of the cell viability was completely abrogated by pretreatment of PC12-F12 cells with $0.5 \% 1$-butanol, but not by its inactive analog 2-butanol. These results confirm the fact that PLD2 activation plays a pivotal role in the inhibitory effect of LPC on serum deprivationinduced cell death.

We next determined the effect of 1-butanol on the LPC-stimulated neurite outgrowth in PLD2-overexpressing PC12-F12 cells induced by the removal of 
A
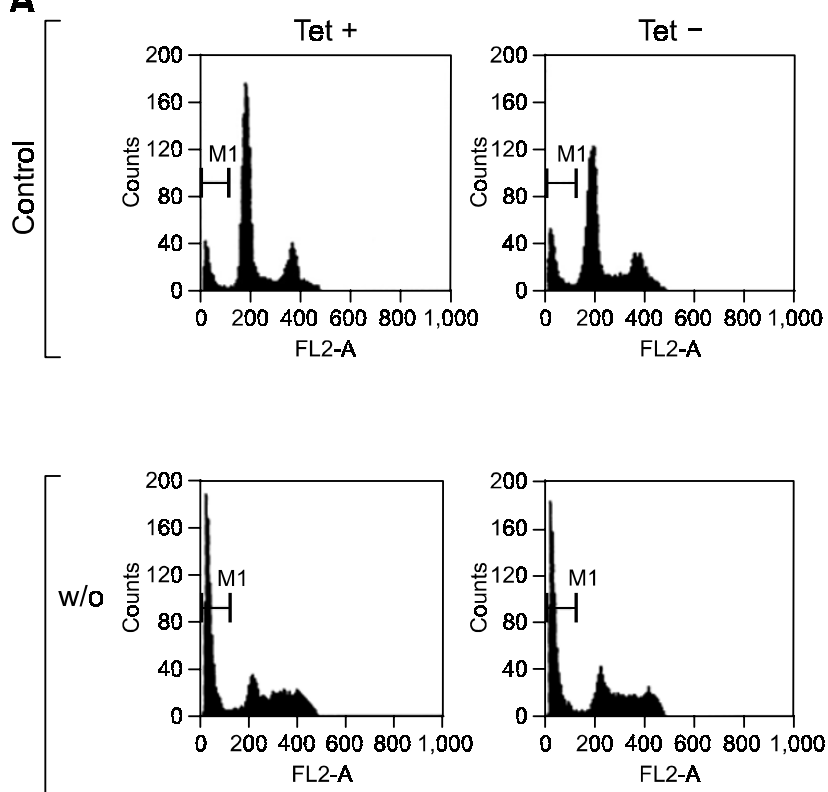

$\stackrel{\text { ᄃ }}{\stackrel{N}{N}}$

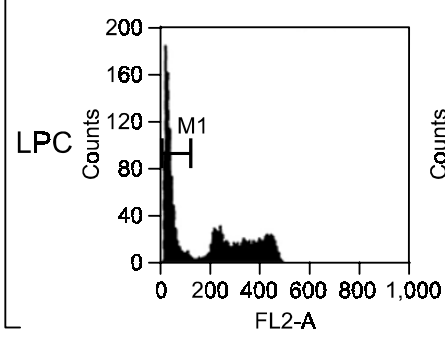

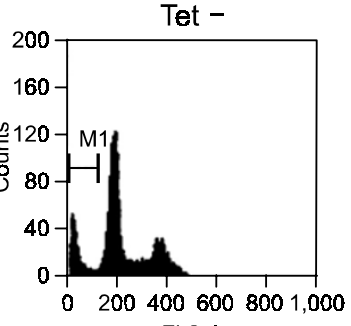

FL2-A

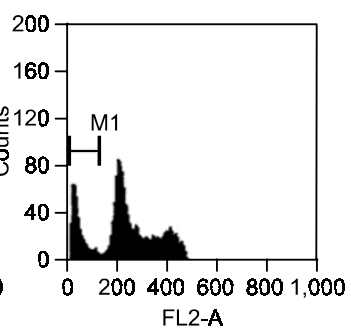

B

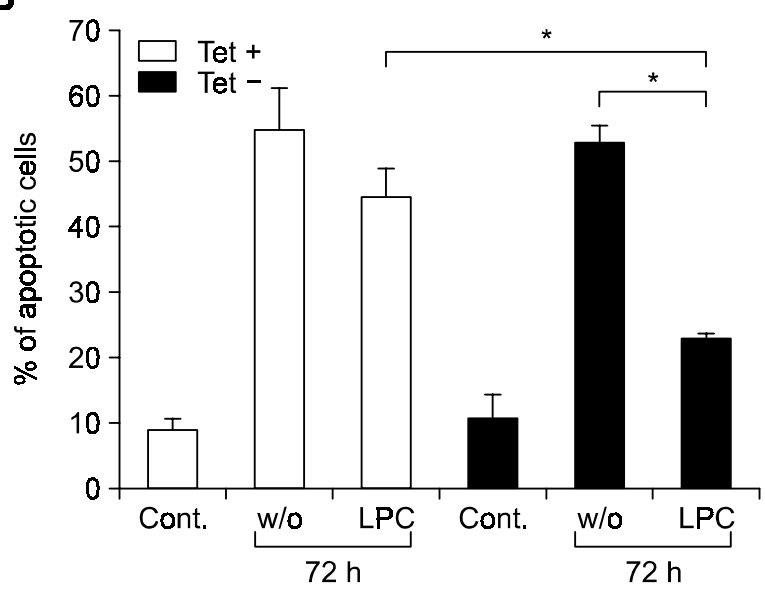

C

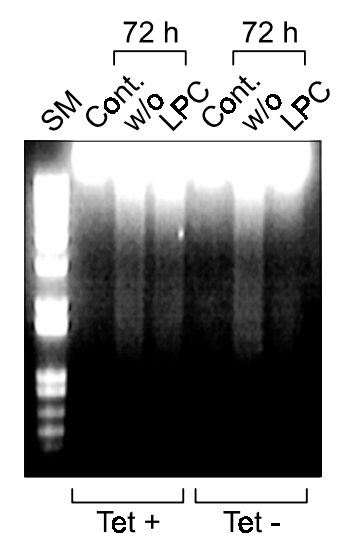

Figure 4. Effects of LPC-stimulated PLD2 activity on the serum starvation-induced apoptosis in PC12 cells. PC12-F12 cells were cultured in growth medium in the absence or presence of $0.5 \mu \mathrm{g} / \mathrm{ml}$ tetracycline for $24 \mathrm{~h}$, and then the cells were exposed to serum-free medium supplemented with 10 $\mu \mathrm{M} \mathrm{LPC}$ (LPC) or vehicles (w/0) for $0 \mathrm{~h}$ (control) or $72 \mathrm{~h}$. (A) The resultant cells were labeled with propidium iodide and analyzed by a FACscan flow cytometer, using the cell Quest software, to quantify a sub-G1 cell population (M1). Data are representatives of three independent experiments. (B) The sub-G1 fractions of cell cycle population were quantified and data are shown as mean \pm S.E. $(n=3)$. * indicates statistical significance $(P<$ 0.05 ). (C) Total DNA was extracted from the PC12-F12 cells, and DNA fragmentation was analyzed by electrophoresis on $1.5 \%$ agarose gel. SM indicates DNA ladder size marker. Representative data from three independent experiments are shown.

tetracycline. As shown in Figure $5 \mathrm{~B}$ and $5 \mathrm{C}$, the LPC-induced neurite outgrowth was completely forestalled by pretreatment of the cells with 1-butanol, but not 2-butanol, further confirming the results that PLD2 activation is required for the LPC-induced neurite outgrowth of PC12 cells.

\section{Discussion}

In the present study, we demonstrated that PLD2 in PC12 cells was specifically activated by LPC treatment. LPC has been shown to play a crucial role in the $\mathrm{Ca}^{2+-}$ dependent activation of PLD2 in L1210 and COS-7 cells (Kim et al., 1999b). PLD2 activity has been reported to be stimulated by
PKC-dependent phosphorylation, interaction with ARF, and several unsaturated fatty acids (Lopez et al., 1998; Kim et al., 1999a; Sung et al., 1999; Han et al., 2002; Kim et al., 2003b; Koch et al., 2003; Chen and Exton, 2004). However, LPC could not activate directly the enzymatic activity of PLD2 in vitro (Kim et al., 1999b). Therefore, it is likely that exogenous LPC may indirectly stimulate the PLD2 activity through activation of some intracellular signaling pathways. Indeed, several G protein-coupled receptors, including G2A and GPR4, have been reported to bind to LPC (Xu, 2002; Meyer zu Heringdorf et al., 2002). LPC induces chemotaxis of macrophages through activation of G2A (Yang et al., 2005), and anti-G2A antibody attenuates protective 
A
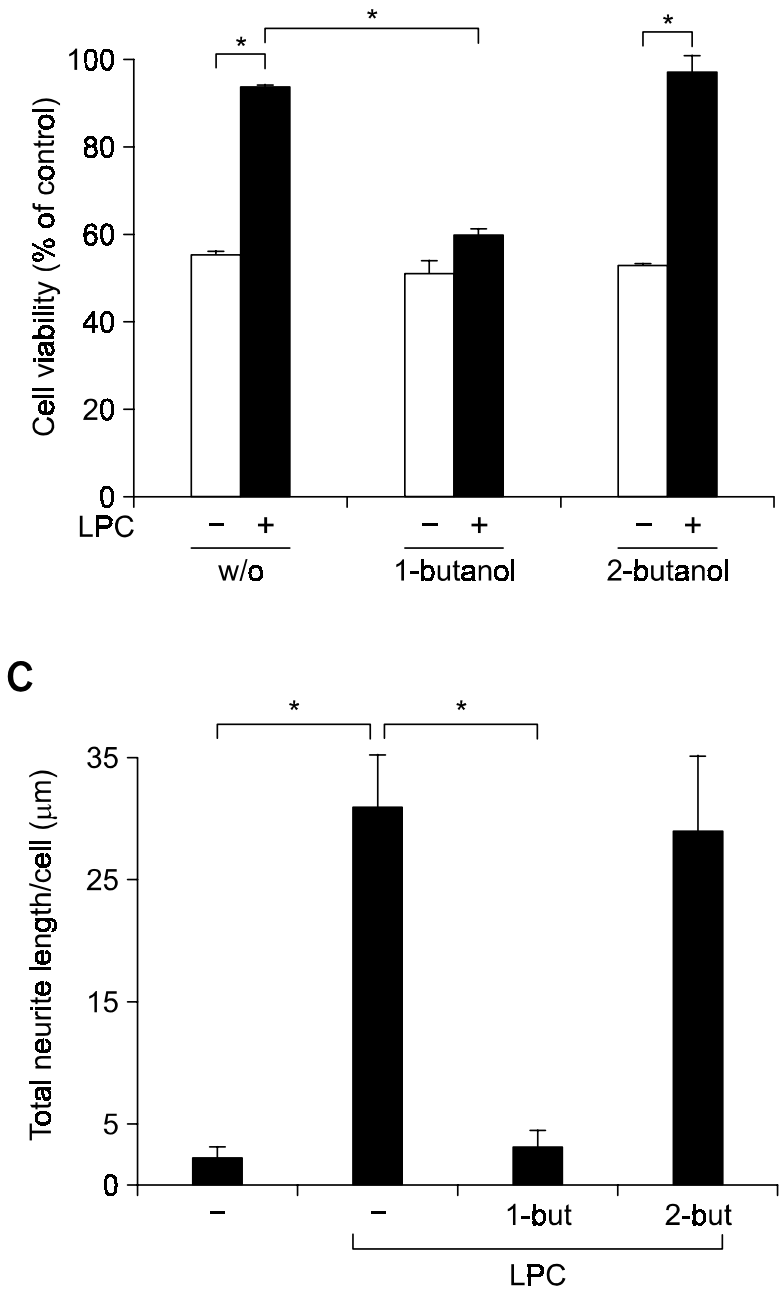

B

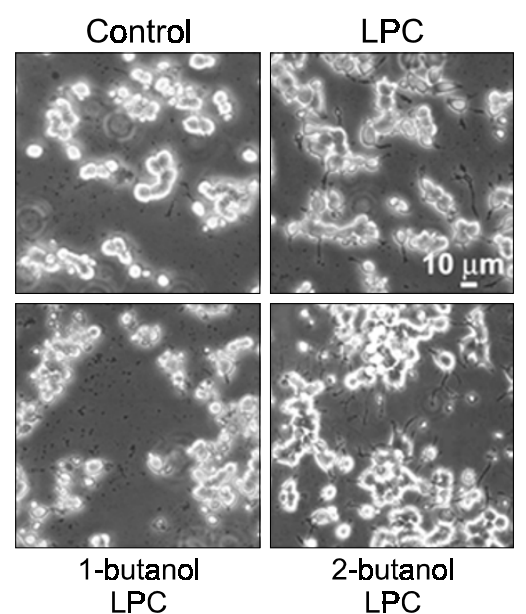

Figure 5. Effects of 1-butanol on the LPC-stimulated survival and neurite outgrowth in PC12 cells. PC12-F12 cells were cultured in growth medium in the absence of tetracycline for $24 \mathrm{~h}$, and then the cells were exposed to serum-free medium supplemented with $10 \mu \mathrm{M} \mathrm{LPC}$ together with $0.5 \%$ 1-butanol or $0.5 \%$ 2-butanol for $72 \mathrm{~h}$. (A) Cell viability was determined by MTT assay. Data are average values \pm S.E. of triplicate determinations. (B) Phase contrast images were photographed by a digital CCD camera equipped in an inverted microscope (Leica $\mathrm{DM}(\mathrm{RB})$ at $\times 200$. Representative data from three idependent experiments are shown. (C) Neurite lengths were measured for 100 cells, and the total neurite length per cell was calculated. The data are mean \pm S.E. * indicates statistical significance $(P<0.05)$. effect of LPC against sepsis-induced lethality in mice (Yan et al., 2004). Furthermore, G2A is endogenously expressed in PC12 cells and activated by LPC treatment (Ikeno et al., 2005). However, several recent studies demonstrated that these receptors can be activated by extracellular proton (Bektas et al., 2003; Tomura et al., 2005), and LPC antagonizes the $\mathrm{pH}$-dependent activation of G2A (Murakami et al., 2004). Therefore, involvement of G2A in LPCinduced cellular responses remains to be clarified.

The biological effect and signaling properties of LPC have extensively been studied in atherosclerosisrelated cells, including endothelial cells, smooth muscle cells, monocytes, and lymphocytes. However, the physiological role of LPC in neuronal cell lines has not yet been fully understood. The present study demonstrated that LPC-induced activation of PLD2 promoted neuritogenesis. Consistent with the stimulatory effect of PLD2 on neurite outgrowth, it has recently been reported that overexpression of PLD2 in PC12 cells elongated neurites induced by NGF stimulation (Watanabe et al., 2004b), and overexpression of PLD2 or treatment with exogenous PA, a second messenger produced by PLD activation, induced neurite outgrowth in cerebellar granule neurons (Watanabe et al., 2004a): PA induces reorganization of actin cytoskeleton and membrane trafficking (Frohman et al., 1999; Liscovitch et al., 2000; Exton, 2002), both of which are essential for neurite outgrowth. Actin cytoskeletal reorganization plays a key role in neurite outgrowth and guidance of primary cultured neurons (Daniels et al., 1998; Dickson, 2002), and PA directly interacts with several actin cytoskeleton-regulatory proteins, including PI4P-5-kinase, protein phosphatase $1 \gamma$, and $\beta$-COP. Moreover, PLD2 localizes in actin cytoskeleton through direct interaction with actin in PC12 cells (Lee et al., 2001). In the present study, we demonstrated that overexpression of PLD2 increased LPCinduced neurite outgrowth, and that inhibition of 
LPC-induced generation of PA by 1-butanol abrogated the LPC-induced neurite outgrowth. These data suggest that LPC-induced activation of PLD2 regulates reorganization of actin cytoskeleton to extend neurite through the generation of PA.

LPA has been involved in neuronal development processes, including neurogenesis, neuronal migration, neuritogenesis, and myelination (Fukushima, 2004; Chun, 2005). LPA can be generated by LPC hydrolysis with autotoxin, a lysophospholipase D (Moolenaar, 2002; Umezu-Goto et al., 2002), which is secreted from astrocytes, oligodendrocytes, and leptomeningeal cells to cerebrospinal fluid of brain (Sato et al., 2005). In contrast to LPC, exogenous LPA has been reported to induce growth cone collapse and neurite retraction of differentiated neuronal cells, including differentiated PC12 cells (Tigyi and Miledi, 1992; Jalink et al., 1993). Therefore, it is tempting to speculate that LPC-derived LPA may counteract the stimulatory effect of LPC on neurite outgrowth, and that the relative ratio of LPC to LPA may be crucial for the regulation of neurite outgrowth of neuronal cells. In addition, it has been reported that PLD2 activity can be suppressed by treatment of PC12 cells with semaphorin 3A (Lee et al., 2002), a chemorepulsive axon guidance molecule, inducing neuronal growth cone collapse (Reza et al., 1999; Nakamura et al., 2000; Raper, 2000). PLD2 activity is inhibited by direct interaction with collapsin response mediator protein-2 (CRMP-2) (Lee et al., 2002), which is a key player in the growth cone collapse of neuronal cells induced by semaphorin 3A (Reza et al., 1999; Nakamura et al., 2000; Raper, 2000) and LPA (Arimura et al., 2000). These above observations suggest that modulation of PLD2 activity plays a crucial role in the regulation of neurite outgrowth induced by LPC, LPA, or semaphorin 3A.

As a neurotrophic factor, NGF has been reported to rescue PC12 cells from serum deprivation-induced apoptosis (Barde, 1994). Our present study demonstrated that LPC-induced PLD2 activation prevented the apoptosis of PC12 cells induced by serum deprivation: Treatment of PLD2-overexpressed PC12 cells with LPC abrogated the serum deprivationinduced cell death, DNA fragmentation, and increased sub-G1 fraction of cell cycle. The antiapoptotic role of PLD2 presently described further supports our earlier study that PLD2 in PC12 cells can be activated by hydrogen peroxide, and that PLD2 activation protects the cells from hydrogen peroxide-induced apoptosis (Lee et al., 2000). Furthermore, overexpression of PLD1 and PLD2 has been shown to abrogate glutamate-induced neuronal cell death (Kim et al., 2003a). Therefore, these results led us to conclude that PLD plays a pivotal role in protection of neuronal cells from apoptotic cell death, and that LPC can act as a new neurotrophic factor in neuronal cells by stimulating PLD2 activity.

\section{Acknowledgement}

This work was supported in part by the MRC program of MOST/KOSEF (R13-2005-009), the Korea Science and Engineering Foundation Grant (R012005-000-10011-02005).

\section{References}

Alley MC, Scudiero DA, Monks A, Hursey ML, Czerwinski MJ, Fine DL, Abbott BJ, Mayo JG, Shoemaker RH, Boyd MR. Feasibility of drug screening with panels of human tumor cell lines using a microculture tetrazolium assay. Cancer Res 1988;48:589-601

Arimura N, Inagaki N, Chihara K, Menager C, Nakamura N, Amano M, Iwamatsu A, Goshima Y, Kaibuchi K. Phosphorylation of collapsin response mediator protein-2 by Rhokinase. Evidence for two separate signaling pathways for growth cone collapse. J Biol Chem 2000;275:23973-80

Barde YA. Neurotrophins: a family of proteins supporting the survival of neurons. Prog Clin Biol Res 1994;390:45-56

Bektas M, Barak LS, Jolly PS, Liu H, Lynch KR, Lacana E, Suhr KB, Milstien S, Spiegel S. The G protein-coupled receptor GPR4 suppresses ERK activation in a ligand-independent manner. Biochemistry 2003;42:12181-91

Chen JS, Exton JH. Regulation of phospholipase D2 activity by protein kinase C alpha. J Biol Chem 2004;279:22076-83

Chun J. Lysophospholipids in the nervous system. Prostaglandins Other Lipid Mediat 2005;77:46-51

Colley WC, Altshuller YM, Sue-Ling CK, Copeland NG, Gilbert DJ, Jenkins NA, Branch KD, Tsirka SE, Bollag RJ, Bollag WB, Frohman MA. Cloning and expression analysis of murine phospholipase D1. Biochem J 1997a;326(Pt 3):745-53

Colley WC, Sung TC, Roll R, Jenco J, Hammond SM, Altshuller Y, Bar-Sagi D, Morris AJ, Frohman MA. Phospholipase D2, a distinct phospholipase $D$ isoform with novel regulatory properties that provokes cytoskeletal reorganization. Curr Biol 1997b;7:191-201

Daniels RH, Hall PS, Bokoch GM. Membrane targeting of p21-activated kinase 1 (PAK1) induces neurite outgrowth from PC12 cells. EMBO J 1998;17:754-64

Dickson BJ. Molecular mechanisms of axon guidance. Science 2002;298:1959-64

Exton JH. Phospholipase D-structure, regulation and function. Rev Physiol Biochem Pharmacol 2002;144:1-94

Frohman MA, Sung TC, Morris AJ. Mammalian phospholipase D structure and regulation. Biochim Biophys Acta 1999; 1439:175-86

Fukushima N. LPA in neural cell development. J Cell Biochem 2004;92:993-1003 
Goodman CS. Mechanisms and molecules that control growth cone guidance. Annu Rev Neurosci 1996;19:341-77

Han JM, Kim JH, Lee BD, Lee SD, Kim Y, Jung YW, Lee S, Cho W, Ohba M, Kuroki T, Suh PG, Ryu SH. Phosphorylation-dependent regulation of phospholipase $\mathrm{D} 2$ by protein kinase $\mathrm{C}$ delta in rat pheochromocytoma PC12 cells. J Biol Chem 2002; 277:8290-7

Ikeno Y, Konno N, Cheon SH, Bolchi A, Ottonello S, Kitamoto $\mathrm{K}$, Arioka M. Secretory phospholipases A2 induce neurite outgrowth in PC12 cells through lysophosphatidylcholine generation and activation of G2A receptor. J Biol Chem 2005; 280:28044-52

Jalink K, Eichholtz T, Postma FR, van Corven EJ, Moolenaar $\mathrm{WH}$. Lysophosphatidic acid induces neuronal shape changes via a novel, receptor-mediated signaling pathway: similarity to thrombin action. Cell Growth Differ 1993;4:247-55

Kim JH, Kim Y, Lee SD, Lopez I, Arnold RS, Lambeth JD, Suh PG, Ryu SH. Selective activation of phospholipase D2 by unsaturated fatty acid. FEBS Lett 1999a;454:42-6

Kim JH, Lee BD, Kim Y, Lee SD, Suh PG, Ryu SH. Cytosolic phospholipase A2-mediated regulation of phospholipase D2 in leukocyte cell lines. J Immunol 1999b;163:5462-70

Kim KO, Lee KH, Kim YH, Park SK, Han JS. Anti-apoptotic role of phospholipase $D$ isozymes in the glutamate-induced cell death. Exp Mol Med 2003a;35:38-45

Kim SW, Hayashi M, Lo JF, Yang Y, Yoo JS, Lee JD. ADP-ribosylation factor 4 small GTPase mediates epidermal growth factor receptor-dependent phospholipase D2 activation. J Biol Chem 2003b;278:2661-8

Koch T, Brandenburg LO, Schulz S, Liang Y, Klein J, Hollt V. ADP-ribosylation factor-dependent phospholipase $D 2$ activation is required for agonist-induced mu-opioid receptor endocytosis. J Biol Chem 2003;278:9979-85

Lee S, Kim JH, Lee CS, Kim JH, Kim Y, Heo K, Ihara Y, Goshima Y, Suh PG, Ryu SH. Collapsin response mediator protein-2 inhibits neuronal phospholipase $\mathrm{D}(2)$ activity by direct interaction. J Biol Chem 2002;277:6542-9

Lee S, Park JB, Kim JH, Kim Y, Kim JH, Shin KJ, Lee JS, Ha $\mathrm{SH}$, Suh PG, Ryu SH. Actin directly interacts with phospholipase D, inhibiting its activity. J Biol Chem 2001;276:28252-60

Lee SD, Lee BD, Han JM, Kim JH, Kim Y, Suh PG, Ryu SH. Phospholipase D2 activity suppresses hydrogen peroxide-induced apoptosis in PC12 cells. J Neurochem 2000; 75:1053-9

Levi A, Biocca S, Cattaneo A, Calissano P. The mode of action of nerve growth factor in PC12 cells. Mol Neurobiol 1988; 2:201-26

Liscovitch M, Czarny M, Fiucci G, Tang X. Phospholipase D: molecular and cell biology of a novel gene family. Biochem J 2000;345 Pt 3:401-15

Lopez I, Arnold RS, Lambeth JD. Cloning and initial characterization of a human phospholipase D2 (hPLD2). ADP-ribosylation factor regulates hPLD2. J Biol Chem 1998;273:12846-52

Macphee $\mathrm{CH}$. Lipoprotein-associated phospholipase A2: a potential new risk factor for coronary artery disease and a ther- apeutic target. Curr Opin Pharmacol 2001;1:121-5

Masuda S, Murakami M, Takanezawa Y, Aoki J, Arai H, Ishikawa Y, Ishii T, Arioka M, Kudo I. Neuronal expression and neuritogenic action of group $X$ secreted phospholipase A2. J Biol Chem 2005;280:23203-14

Meyer zu Heringdorf D, Himmel HM, Jakobs KH. Sphingosylphosphorylcholine-biological functions and mechanisms of action. Biochim Biophys Acta 2002;1582:178-89

Moolenaar WH. Lysophospholipids in the limelight: autotaxin takes center stage. J Cell Biol 2002;158:197-9

Mueller BK. Growth cone guidance: first steps towards a deeper understanding. Annu Rev Neurosci 1999;22:351-88

Murakami N, Yokomizo T, Okuno T, Shimizu T. G2A is a proton-sensing G-protein coupled receptor antagonized by lysophosphatidylcholine. J Biol Chem 2004;279:42484-91

Nakamura F, Kalb RG, Strittmatter SM. Molecular basis of semaphorin-mediated axon guidance. J Neurobiol 2000; 44:219-29

Park SK, Provost JJ, Bae CD, Ho WT, Exton JH. Cloning and characterization of phospholipase $D$ from rat brain. J Biol Chem 1997;272:29263-71

Paves $\mathrm{H}$, Saarma M. Neurotrophins as in vitro growth cone guidance molecules for embryonic sensory neurons. Cell Tissue Res 1997;290:285-97

Prokazova NV, Zvezdina ND, Korotaeva AA. Effect of lysophosphatidylcholine on transmembrane signal transduction. Biochemistry (Mosc.) 1998;63:31-7

Raper JA. Semaphorins and their receptors in vertebrates and invertebrates. Curr Opin Neurobiol 2000;10:88-94

Reza JN, Gavazzi I, Cohen J. Neuropilin-1 is expressed on adult mammalian dorsal root ganglion neurons and mediates semaphorin3a/collapsin-1-induced growth cone collapse by small diameter sensory afferents. Mol Cell Neurosci 1999; 14:317-26

Sato K, Malchinkhuu E, Muraki T, Ishikawa K, Hayashi K, Tosaka M, Mochiduki A, Inoue K, Tomura H, Mogi C, Nochi H, Tamoto K, Okajima F. Identification of autotaxin as a neurite retraction-inducing factor of PC12 cells in cerebrospinal fluid and its possible sources. J Neurochem 2005;92:904-14

Sung TC, Altshuller YM, Morris AJ, Frohman MA. Molecular analysis of mammalian phospholipase D2. J Biol Chem 1999; 274:494-502

Tigyi G, Miledi R. Lysophosphatidates bound to serum albumin activate membrane currents in Xenopus oocytes and neurite retraction in PC12 pheochromocytoma cells. J Biol Chem 1992;267:21360-7

Tomura H, Mogi C, Sato K, Okajima F. Proton-sensing and lysolipid-sensitive G-protein-coupled receptors: a novel type of multi-functional receptors. Cell Signal 2005;17:1466-76

Umezu-Goto M, Kishi Y, Taira A, Hama K, Dohmae N, Takio K, Yamori T, Mills GB, Inoue K, Aoki J, Arai H. Autotaxin has lysophospholipase $\mathrm{D}$ activity leading to tumor cell growth and motility by lysophosphatidic acid production. J Cell Biol 2002; 158:227-33 
Watanabe H, Yamazaki M, Miyazaki H, Arikawa C, Itoh K, Sasaki T, Maehama T, Frohman MA, Kanaho Y. Phospholipase D2 functions as a downstream signaling molecule of MAP kinase pathway in L1-stimulated neurite outgrowth of cerebellar granule neurons. J Neurochem 2004a;89:142-51

Watanabe H, Yokozeki T, Yamazaki M, Miyazaki H, Sasaki T, Maehama T, Itoh K, Frohman MA, Kanaho Y. Essential role for phospholipase D2 activation downstream of ERK MAP kinase in nerve growth factor-stimulated neurite outgrowth from PC12 cells. J Biol Chem 2004b;279:37870-7

$\mathrm{Xu}$ Y. Sphingosylphosphorylcholine and lysophosphatdylcholine: $\mathrm{G}$ protein-coupled receptors and receptor-mediated sig- nal transduction. Biochim Biophys Acta 2002;1582:81-8

Yan JJ, Jung JS, Lee JE, Lee J, Huh SO, Kim HS, Jung KC, Cho JY, Nam JS, Suh HW, Kim YH, Song DK. Therapeutic effects of lysophosphatidylcholine in experimental sepsis. Nat Med 2004;10:161-7

Yang LV, Radu CG, Wang L, Riedinger M, Witte ON. Gi-independent macrophage chemotaxis to lysophosphatidylcholine via the immunoregulatory GPCR G2A. Blood 2005; 105:1127-34

Zheng JQ, Wan JJ, Poo MM. Essential role of filopodia in chemotropic turning of nerve growth cone induced by a glutamate gradient. J Neurosci 1996;16:1140-9 